\title{
The Interaction between Tropomyosin-Related Kinase B Receptors and Presynaptic Muscarinic Receptors Modulates Transmitter Release in Adult Rodent Motor Nerve Terminals
}

\author{
Neus Garcia, Marta Tomàs, Manel M. Santafé, Nuria Besalduch, Maria A. Lanuza, and Josep Tomàs \\ Unitat d'Histologia i Neurobiologia, Facultat de Medicina i Ciències de la Salut, Universitat Rovira i Virgili, 43201 Reus, Spain
}

\begin{abstract}
The neurotrophin brain-derived neurotrophic factor (BDNF), neurotrophin-4 (NT-4) and the receptors tropomyosin-related kinase B (trkB) and $75^{\mathrm{NTR}}$ are present in the nerve terminals on the neuromuscular junctions (NMJs) of the levator auris longus muscle of the adult mouse. Exogenously added BDNF or NT-4 increased evoked ACh release after $3 \mathrm{~h}$. This presynaptic effect (the size of the spontaneous potentials is not affected) is specific because it is not produced by neurotrophin-3 (NT-3) and is prevented by preincubation with trkB-IgG chimera or by pharmacological block of trkB $\left[\mathrm{K}-252 \mathrm{a}\left(\mathrm{C}_{27} \mathrm{H}_{21} \mathrm{~N}_{3} \mathrm{O}_{5}\right)\right]$ or p $75^{\mathrm{NTR}}\left[\mathrm{Pep} 5\left(\mathrm{C}_{86} \mathrm{H}_{111} \mathrm{~N}_{25} \mathrm{O}_{19} \mathrm{~S}_{2}\right)\right]$ signaling. The effect of BDNF depends on the $\mathrm{M}_{1}$ and $\mathrm{M}_{2}$ muscarinic acetylcholine autoreceptors ( $\mathrm{mAChRs}$ ) because it is prevented by atropine, pirenzepine and methoctramine. We found that K-252a incubation reduces ACh release $(\sim 50 \%)$ in a short time $(1 \mathrm{~h})$, but the p $75^{\mathrm{NTR}}$ signaling inhibitor Pep5 does not have this effect. The specificity of the K-252a blocking effect on trkB was confirmed with the anti-trkB antibody 47/trkB, which reduces evoked ACh release, like K-252a, whereas the nonpermeant tyrosine kinase blocker K-252b does not. Neither does incubation with the fusion protein trkB-IgG (to chelate endogenous BDNF/NT-4), anti-BDNF or anti-NT-4 change ACh release. Thus, the trkB receptor normally seems to be coupled to ACh release when there is no short-term local effect of neurotrophins at the NMJ. The normal function of the $\mathrm{mAChR}$ mechanism is a permissive prerequisite for the trkB pathway to couple to ACh release. Reciprocally, the normal function of trkB modulates $\mathrm{M}_{1}$ - and $\mathrm{M}_{2}$-subtype muscarinic pathways.
\end{abstract}

\section{Introduction}

Several local signaling molecules from presynaptic and postsynaptic sites and the surrounding glia coordinate the complex molecular machinery of synapses. At the presynaptic level, membrane receptors for these mediators control the functional conditions of transmitter release in response to variable activity demands. In the neuromuscular synapse, muscarinic acetylcholine autoreceptors (mAChRs) (Caulfield, 1993; Slutsky et al., 1999; Minic et al., 2002; Santafé et al., 2003, 2004; Garcia et al., 2005), adenosine receptors (Song et al., 2000), neurotrophin receptors (Bibel and Barde, 2000; Roux and Barker, 2002; Pitts et al., 2006), and receptors for other trophic factors cooperate to produce synaptic plasticity.

Presynaptic mAChRs directly couple ACh secretion to the regulation of the release mechanism itself (Santafé et al., 2007). Adenosine triphosphate released by nerve endings modulates presynaptic metabolism through purinergic autoreceptors (Correia-de-Sa et al., 1991). The postsynaptic muscle cells provide target-derived neurotrophins, which regulate the growth and maintenance of presynaptic motor neurons (Lewin and

\footnotetext{
Received May 26, 2010; revised Sept. 16, 2010; accepted Sept. 22, 2010.

This work was supported by Ministerio de Edicación y Ciencia Grant SAF 2008-02836 and Catalan Government (Generalitat) Grant 2009SGR01248.

Correspondence should be addressed to Drs. Neus Garcia, Manel M. Santafé or Josep Tomas, Unitat d'Histologia i Neurobiologia, Facultat de Medicina i Ciències de la Salut, Universitat Rovira i Virgili, Carrer Sant Llorenç, 21, 43201Reus, Spain, E-mail:nsg@fmcs.urv.es, msm@fmcs.urv.es, or jmtf@fmcs.urv.es.

DOI:10.1523/JNEUROSCI.2676-10.2010

Copyright $\odot 2010$ the authors $\quad$ 0270-6474/10/3016514-09\$15.00/0
}

Barde, 1996; Wang and Poo, 1997; Bibel and Barde, 2000; Roux et al., 2006) through specific tyrosine kinase (trk) receptors (and one unspecific receptor, $\left.\mathrm{p} 75^{\mathrm{NTR}}\right)$. Brain-derived neurotrophic factor (BDNF) and neurotrophin-4 (NT-4) are members of the neurotrophin family that bind to the high-affinity receptor tropomyosin-related kinase B (trkB) (Barde et al., 1982; Barbacid, 1994).

These metabotropic receptors are coupled to various intracellular pathways, although they can share several signaling links from the limited repertoire of presynaptic effector kinases, target ionic channels, and other molecules of the release machinery. In fact, the final synapse operation may be the result of the functional confluence of several metabotropic receptor-mediated signaling pathways turned on or off in an activity-dependent manner. For instance, it has been shown that adenosine can activate trk receptor phosphorylation through purinergic receptor $2 \mathrm{~A}$, and this activation does not require neurotrophin binding (Lee and Chao, 2001; Wiese et al., 2007) to activate a trophic response in motoneurons. The transactivation of receptor tyrosine kinases in response to G-protein-coupled receptor signaling is well documented (Daub et al., 1996; Fischer et al., 2003).

Here, we used electrophysiology to investigate the functional interactions between the mAChR- and the trkB-mediated signaling mechanisms and their coordinated role in transmitter release and synaptic activity. We tested the overall hypothesis that the G-protein-coupled muscarinic receptors are involved in the transactivation and coupling to transmitter release of the trkB receptor. We found that the trkB receptor is normally coupled to 
ACh release in the absence of a short-term local effect of neurotrophins at the neuromuscular junction (NMJ). The normal function of the $\mathrm{mAChR}$ mechanism is a permissive condition for the trkB pathway to couple to ACh release. Reciprocally, the trkB normal function modulates $\mathrm{M}_{1}$ and $\mathrm{M}_{2}$ muscarinic pathways.

\section{Materials and Methods}

Animals

Experiments were performed on the levator auris longus (LAL) muscle of adult male Swiss mice [postnatal day (P30)-P40; Criffa]. The mice were cared for in accordance with the guidelines of the European Community's Council Directive of November 24, 1986 (86/609/EEC) for the humane treatment of laboratory animals. The animals were anesthetized with $2 \%$ tribromoethanol $(0.15 \mathrm{ml} / 10 \mathrm{~g}$ of body weight, i.p. $)$.

\section{Immunohistochemistry}

Whole mounts of LAL were processed to simultaneously detect the different neurotrophins (BDNF or NT-4) and their trkB and $\mathrm{p} 75^{\mathrm{NTR}}$ receptors with postsynaptic nicotinic acetylcholine receptors (nAChRs) and syntaxin. nAChRs were stained with tetramethyl rhodamine isothiocyanate (TRITC)- $\alpha$-BTX. Muscles were incubated overnight at $4^{\circ} \mathrm{C}$ with the rabbit antibody against BDNF (1:200; Santa Cruz Biotechnology), NT-4 (1:200; Millipore Bioscience Research Reagents), trkB (1: 1000; Santa Cruz Biotechnology), and goat p $75^{\text {NTR }}$ (1:100), and a mouse anti-syntaxin monoclonal antibody (1:1000; Sigma) in 1\% BSA. The two appropriate secondary antibodies conjugated with Alexa Fluor 488 or Alexa Fluor 647 were then added and incubated for $4 \mathrm{~h}$. Muscle fibers were mounted in Mowiol with $p$-phenylenediamide (Sigma). To test the specificity of the antibodies used, we tested the anti-BDNF, antiNT-4, anti-trkB, and anti-p75 ${ }^{\text {NTR }}$ antibodies with immunoblots of homogenates of the adult muscle and adult spinal cord (Garcia et al., 2010c). Also, at least three muscles were used as negative controls in the immunohistochemistry: one muscle was incubated in the absence of primary antibody, a second muscle was incubated with a specific primary antibody and a nonspecific secondary antibody, and a third muscle was incubated to show a possible cross-linking between the primary antibodies that joined the secondary antibodies. A detailed description of these controls was reported previously (Garcia et al., 2010c). In addition, we assayed negative control solutions prepared with blocking peptides or normal IgG. Negative control solutions for rabbit polyclonal antibody for BDNF were prepared by absorbing equal volumes of the diluted primary antibody with the corresponding concentrated blocking peptide (sc-446P; Santa Cruz Biotechnology). A normal rabbit IgG antibody (1:1000) served as a negative control for the rabbit polyclonal antibodies for trkB receptor (sc-2027; Santa Cruz Biotechnology). For NT-4, the recombinant human NT-4 peptide (GF032; Millipore Bioscience Research Reagents) was used. Negative control solutions for goat polyclonal antibody for $\mathrm{p} 75$ were prepared by absorbing equal volumes of the diluted primary antibody with the corresponding concentrated blocking peptide (sc6188P; Santa Cruz Biotechnology). In all cases, the immunostaining was completely abolished. NMJs were viewed with an inverted Nikon TE2000 microscope, and three-dimensional reconstructions were generated. The BDNF rabbit polyclonal antibody (N-20; sc-546), the trkB rabbit polyclonal antibody (H-181; sc-8316), and the $\mathrm{p} 75^{\mathrm{NTR}}$ goat polyclonal antibody (C-20; sc-6188) were purchased from Santa Cruz Biotechnology, and the NT-4 rabbit polyclonal antibody (AB1781) was purchased from Millipore Bioscience Research Reagents. The mouse monoclonal anti-syntaxin antibody (1:1000) was purchased from Sigma. The secondary antibodies (donkey Alexa Fluor 488 anti-rabbit, donkey Alexa Fluor 488 anti-goat, and donkey Alexa Fluor 647 anti-mouse) were purchased from Invitrogen. Postsynaptic nAChRs were detected with TRITC- $\alpha$-BTX (Invitrogen).

To confirm the presence of the BDNF, NT-4, trkB, and $\mathrm{p} 75^{\mathrm{NTR}}$ proteins in the nerve terminals, we used plastic-embedded semithin sections for high-resolution immunofluorescence analysis of the neuromuscular junction molecules (Lanuza et al., 2007). Briefly, this method used the protocol described above to process the muscles by triple immunohistochemistry and simultaneously detect nAChRs, S-100, and one of the proteins studied. Muscles were incubated overnight with one of the an- tibodies described above and mouse anti-S-100 (1:10,000; Dako) in 1\% BSA. The appropriate secondary antibodies conjugated with Alexa Fluor 488 or Alexa Fluor 647 were then added and incubated for $4 \mathrm{~h}$. nAChRs were stained with TRITC- $\alpha$-BTX. Then, the muscles were dehydrated with increasing concentrations of ethanol and acetone, and the tissue fragments were embedded in Spurr's resin in transverse orientation. Sections 0.5 to $0.7 \mu \mathrm{m}$ thick were cut with a Reichert Ultracut E microtome (Leica Microsystems) and flattened on glass slides by heating on a hotplate. Also, a triple-staining labeling of postsynaptic nAChRs, syntaxin, and S-100 was performed to evidenciate the good separation of the specific molecular markers of the three synaptic cells.

\section{Electrophysiological recordings}

The LAL muscle with its nerve supply was excised and dissected on a Sylgard-coated Petri dish containing normal Ringer's solution containing the following (in mM): $137 \mathrm{NaCl}, 5 \mathrm{KCl}, 2 \mathrm{CaCl}_{2}, 1 \mathrm{MgSO}_{4}, 12$ $\mathrm{NaHCO}_{3}, 1 \mathrm{Na}_{2} \mathrm{HPO}_{4}$, and 11 glucose, continuously bubbled with $95 \%$ $\mathrm{O}_{2} / 5 \% \mathrm{CO}_{2}$. The preparation was then transferred to a recording chamber of $1.5 \mathrm{ml}$. Experiments were performed at room temperature (22$\left.25^{\circ} \mathrm{C}\right)$. The bath temperature was monitored during experiments $(23.4 \pm$ $1.7^{\circ} \mathrm{C}$; digital thermometer TMP 812 ; Letica). Endplate potentials (EPPs) were recorded intracellularly with conventional glass microelectrodes filled with $3 \mathrm{M} \mathrm{KCl}$ (resistance, 20-40 M $\Omega$ ). Recording electrodes were connected to an amplifier (Tecktronics; AMS02), and a distant $\mathrm{Ag}-\mathrm{AgCl}$ electrode connected to the bath solution via an agar bridge (3.5\% agar in $137 \mathrm{~mm} \mathrm{NaCl}$ ) was used as reference. The signals were digitized (DIGIDATA 1322A interface; Molecular Devices), stored, and computer analyzed. The software Axoscope 9.0 (Molecular Devices) was used for data acquisition and analysis.

In previous studies on mAChR drugs (Santafé et al., 2003), protein kinase C drugs (Santafé et al., 2005), and protein kinase A drugs (Santafé et al., 2006), standard sharp-electrode intracellular recording techniques were used to show that miniature EPP (MEPP) amplitudes and postsynaptic resting membrane potentials were unaffected, and therefore, that all of the compounds used act presynaptically in the present conditions. We also analyzed the effects of BDNF, NT-4, and K-252a on the MEPPs. In addition, when consecutive incubations were performed with two different substances, we investigated whether there was a final change in the MEPP amplitude, and we found in all cases that the MEPP amplitude did not change.

To prevent muscle contraction during EPP recordings, we used $\mu$-conotoxin GIIIB ( $\mu$-CgTx-GIIIB; $3 \mu \mathrm{M})$. After a muscle fiber had been impaled, the nerve was continuously stimulated (70 stimuli at $0.5 \mathrm{~Hz}$ ) using two platinum electrodes that were coupled to a pulse generator (Cibertec CS-20) linked to a stimulus isolation unit. We recorded the last 50 EPPs and used only those results from preparations that had a resting potential of less than $-50 \mathrm{mV}$ and that did not deviate by $>5 \mathrm{mV}$ during the experimental paradigms. The mean amplitude (in millivolts) per fiber was calculated and corrected for nonlinear summation (EPPs were usually $>4 \mathrm{mV}$ ) (McLachlan and Martin, 1981), assuming a membrane potential of $-80 \mathrm{mV}$. We studied a minimum of 15 fibers per muscle and usually a minimum of five muscles in each type of experiment. In the single-fiber experiments (time course of the effect of drugs on EPPs of the same fiber permanently impaled), the $\operatorname{drug}(\mathrm{s})$ were added to the bathing solution, and EPPs were recorded as described previously every $15 \mathrm{~min}$ for a minimum of $120 \mathrm{~min}$.

Values are expressed as means \pm SEM. We used a one-way ANOVA to evaluate differences between groups and the Bonferroni test for multiple comparisons. When differences were evaluated between only two groups, we used the two-tailed Welch's $t$ test (for unpaired values and not assuming equal variances). Differences were considered significant at $p<0.05$.

\section{Western immunoblotting}

Quantitative Western blotting analysis of trkB and tyrosine trkB phosphorylation was performed. The LAL muscle was excised and dissected on a Sylgard-coated Petri dish containing normal Ringer's solution. We analyzed the effects of BDNF ( $10 \mathrm{~nm} ; 3 \mathrm{~h}$ ), atropine ( $2 \mu \mathrm{M} ; 1 \mathrm{~h}$ ), methoctramine $(1 \mu \mathrm{M} ; 1 \mathrm{~h})$, and pirenzepine $(10 \mu \mathrm{M} ; 1 \mathrm{~h})$ on the expression and level of tyrosine phosphorylation of the trkB protein. We analyzed also 
A
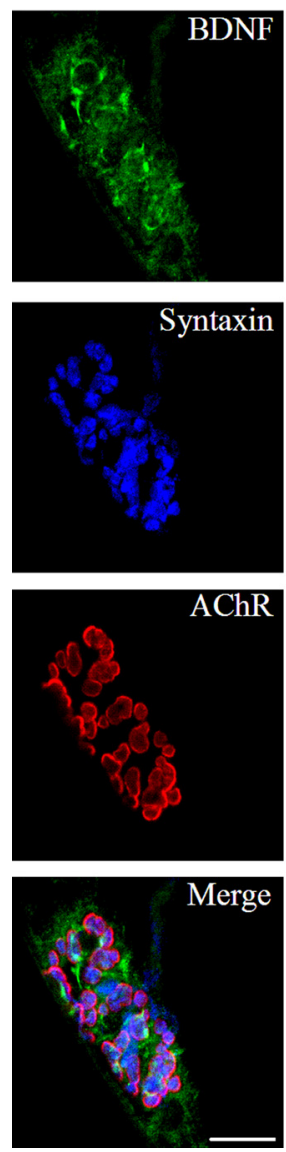

B
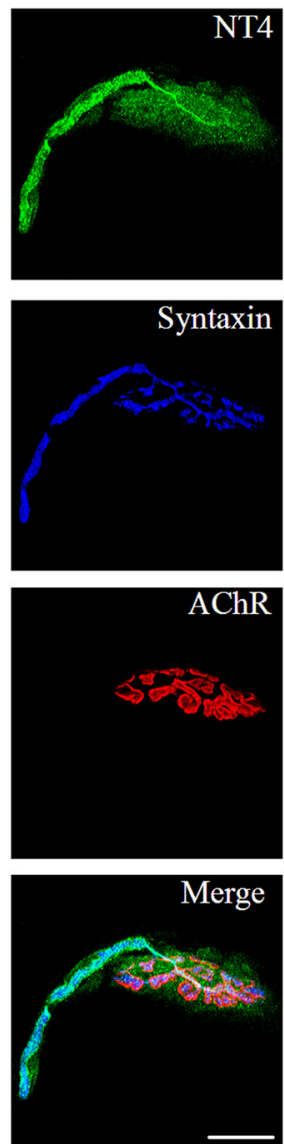

C
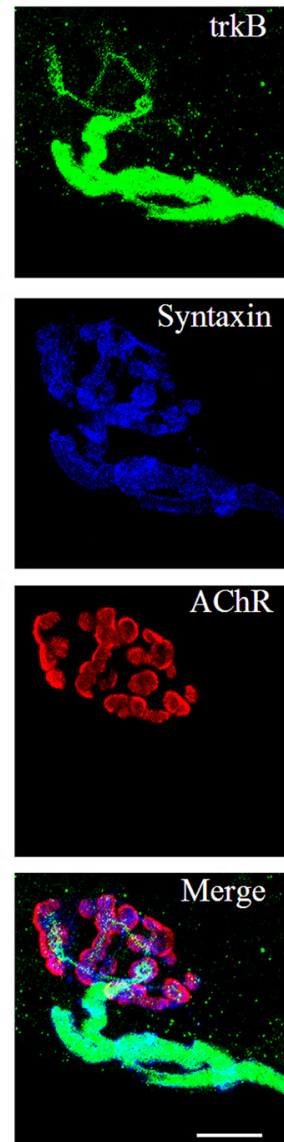

D
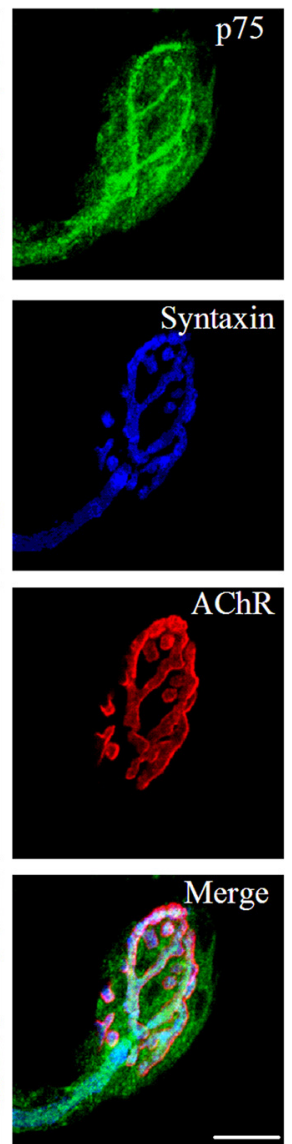

E
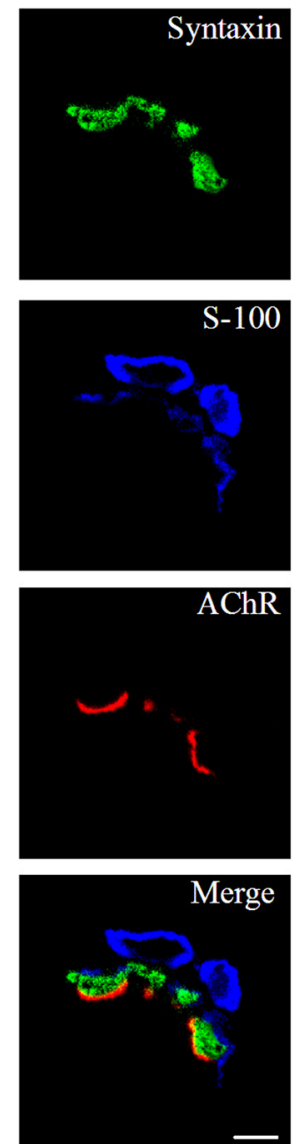

$\mathbf{F}$
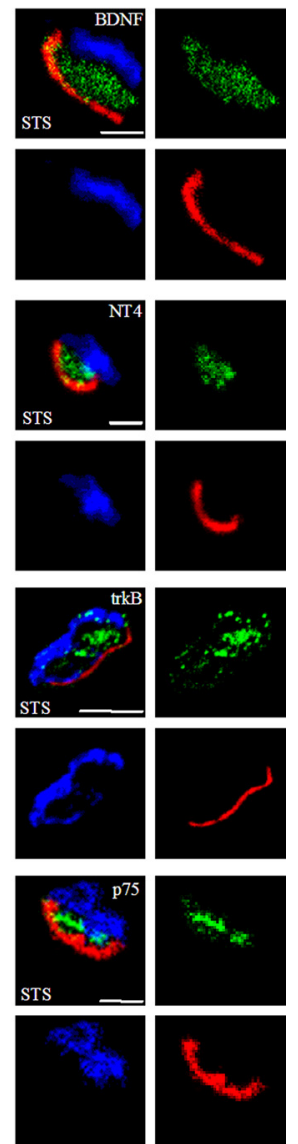

Figure 1. Immunolocalization of BDNF, NT-4, trkB, and p75 NTR at the neuromuscular synapses. $\boldsymbol{A}-\boldsymbol{D}$, Triple labeling of the neurotrophins BDNF $(\boldsymbol{A})$ and NT-4 $(\boldsymbol{B})$ and their receptors trkB $(\boldsymbol{C})$ and p75 ${ }^{\text {NTR }}(\boldsymbol{D})$ (green fluorescence) with syntaxin (blue fluorescence) and AChR- $\alpha$ bungarotoxin (red fluorescence). We used plastic-embedded semithin (0.5 to $0.7 \mu \mathrm{m}$ ) cross-sections (STS) as a tool for high-resolution, triple-labeling immunofluorescence analysis. $\boldsymbol{E}$, Example of triple labeling of syntaxin (green fluorescence), $\mathrm{S}-100$ (blue fluorescence), and $\mathrm{nAChR-} \alpha$ bungarotoxin (red fluorescence), which proves that the molecular markers of the three synaptic cells are separated well. $\boldsymbol{F}$, High-resolution images of synaptic boutons with the terminal axon labeled for one of the proteins in green in the nerve terminal area between the blue Schwann cell and the red nAChR cluster. Scale bars: $\boldsymbol{A}-\boldsymbol{E}, 10 \mu \mathrm{m} ; \boldsymbol{F}, 1 \mu \mathrm{m}$.

the effects of atropine, methoctramine, and pirenzepine on the expression of BDNF and NT-4 in the muscle. LAL muscles were homogenized $(1: 10 \mathrm{w} / \mathrm{v})$ at $4^{\circ} \mathrm{C}$ in buffer A containing $50 \mathrm{~mm}$ Tris, ph 7.4, 2 mM EDTA, $1 \% \mathrm{NP} 40,150 \mathrm{~mm} \mathrm{NaCl}, 10 \%$ glycerol, $10 \mu \mathrm{g} / \mathrm{ml}$ PMSF, $50 \mathrm{~mm} \mathrm{NaF,} 1$ mM sodium orthovanadate $\left(\mathrm{Na}_{3} \mathrm{VO}_{4}\right)$, and a protease inhibitor mixture [1.4 mм AEBSF (4-[2-aminoethyl] benzenesulfonyl fluoride hydrochloride), $0.8 \mu \mathrm{M}$ aprotinin, $0.02 \mu \mathrm{M}$ leupeptin, $0.04 \mu \mathrm{M}$ bestain, $0.015 \mu \mathrm{M}$ pepstatin A, $0.015 \mu \mathrm{M}$ E-64; Sigma]. After the insoluble material had been extracted by centrifugation at $4000 \times g$ for $5 \mathrm{~min}$, samples were centrifuged at $15,000 \times g$ for $15 \mathrm{~min}$ and the supernatants were the lysate samples. Protein concentrations were determined using the Bio-Rad protein assay. Samples $(50 \mu \mathrm{g})$ were electrophoresed on $8 \%$ SDSpolyacrylamide gels (Laemmli, 1970). Then they were transferred to polyvinylidene difluoride (PVDF) membranes (GE Healthcare). The PVDF membranes were blocked in 5\% nonfat milk in Tris-buffered saline (50 mm Tris, $\mathrm{pH} 7.4,200 \mathrm{~mm} \mathrm{NaCl}, 0.1 \%$ Triton X-100, 0.2\% Tween 20 ) and then incubated with the corresponding primary antibodies anti$\operatorname{trkB}(1: 1000)$, anti-phospho-trkB (1:300), anti-BDNF (1:1000), and antiNT-4 (1:1000). Horseradish peroxidase-conjugated secondary antibody from Jackson Immunoresearch was used at a dilution of 1:20,000 and revealed by chemiluminescence with the ECL kit (GE Healthcare). As a negative control, the primary antibody was omitted. The densitometry program Phoretix (Nonlinear Dynamics) was used to analyze the density of different bands. Data were taken from densitometry measurements made in at least five separate experiments, plotted against controls, and normalized by actin protein. The integrated optical density of the bands was normalized to the background values. The relative variations be- tween the bands in the experimental samples and the control samples were calculated in the same image. Data are mean values \pm SD. Differences between groups were tested using the $t$ test or $U$ test (MannWhitney), and the normality of the distributions was tested with the Kolmogorov-Smirnov test. Percentages were compared with the $\chi^{2}$ or Fisher test. The criterion for statistical significance was $p<0.05$ versus the control. The rabbit polyclonal antibody trkB (794; sc-12) was purchased from Santa Cruz Biotecnology, and monoclonal antibody antiphospho-trkB-pY817 was purchased from Epitomic. The rabbit polyclonal antibody BDNF (N-20; sc-546) was purchased from Santa Cruz Biotechnology, and the rabbit polyclonal antibody NT-4 (AB1781) was purchased from Millipore Bioscience Research Reagents.

\section{Chemicals}

Muscarinic agents. Stock solutions used were atropine (200 $\mu$ m; Sigma) and pirenzepine dihydrochloride (10 mM; Tocris Bioscience). Working solutions used were atropine $(2 \mu \mathrm{M})$, methoctramine $(1 \mu \mathrm{M})$, and pirenzepine $(10 \mu \mathrm{M})$.

trkB receptor-related agents. Stock solutions used were as follows: antiBDNF (G2610; Promega), $50 \mu \mathrm{g} / \mathrm{ml}$; anti-NT-4 (AB1781; Millipore Bioscience Research Reagents), $50 \mu \mathrm{g} / \mathrm{ml}$; anti-trkB (clone 47/trkB; 610102; BD Transduction Laboratories), $250 \mu \mathrm{g} / \mathrm{ml}$; human BDNF (Alomone Labs), $0.37 \mu \mathrm{M}$; human NT-4 (Alomone Labs), $40 \mathrm{~nm}$; K-252a (Calbiochem), $5 \mathrm{~mm}$ in DMSO; K-252b (Calbiochem), 5 mm; Pep5 (Calbiochem), $100 \mu \mathrm{M}$; recombinant human trkB/Fc Chimera (trkB-Fc; 688-TK; R\&D Systems), $100 \mu \mathrm{g} / \mathrm{ml}$. Working solutions were as follows: antiBDNF, 2-20 $\mu \mathrm{g} / \mathrm{ml}$; anti-NT-4, 5-20 $\mu \mathrm{g} / \mathrm{ml}$; anti-trkB, $10 \mu \mathrm{g} / \mathrm{ml}$; BDNF, 
10 nм; K-252a, 200 nм; NT-4, 2 nм; K-252b, 100-500 nм; Pep5, $1 \mu \mathrm{m}$; trkB-Fc, $1-5 \mu \mathrm{g} / \mathrm{ml}$.

All stock solutions were stored at $4^{\circ} \mathrm{C}$ for $<4$ weeks. We chose concentrations of drugs that did not change the size of the MEPPs in concentration-response curves performed in previous experiments. Experiments in the presence of K-252a were performed with no direct illumination. The final DMSO concentration in control and drug-treated preparations was $0.1 \%(\mathrm{v} / \mathrm{v})$. In control experiments, this concentration of DMSO did not affect any of the parameters studied (data not shown).

\section{Results}

Localization of BDNF, NT-4, trkB, and $\mathrm{p} 75^{\mathrm{NTR}}$ by immunohistochemistry on the adult LAL skeletal muscle

By triple labeling one of these proteins (green fluorescence, BDNF, NT-4, trkB, or p75 ${ }^{\mathrm{NTR}}$ ) with syntaxin (blue fluorescence) and $\mathrm{nAChR}-\alpha$-bungarotoxin (red fluorescence), we saw that the molecules were present in the neuromuscular contacts (Fig. $1 A-$ $D$ ). However, the three cellular components of the NMJ (the nerve terminal, the perisynaptic Schwann cells, and the postsynaptic muscle fiber) were closely juxtaposed, and it was not easy to precisely locate the molecules. We used plastic-embedded semithin $(0.5$ to $0.7 \mu \mathrm{m})$ cross-sections as a tool for high-resolution, triple-labeling immunofluorescence analysis. Figure $1 E$ shows an example of triple labeling of syntaxin (green fluorescence), S-100 (blue fluorescence), and nAChR- $\alpha$ bungarotoxin (red fluorescence), which proves that the specific molecular markers of the three synaptic cells are separated well by this procedure. Figure $1 F$ shows synaptic boutons with the terminal axon labeled for one of the neurotrophin or receptor proteins (green) in the nerve terminal area between the Schwann cell (blue label) and nAChR cluster (red label). The nonspecific background was almost absent. There is, then, strong immunoreactivity in the terminal and preterminal motor axons (Garcia et al., 2010b,c).

\section{Effect of exogenous BDNF and NT-4 on neuromuscular transmission}

The dose-response study in Fig. $2 \mathrm{~A}$ shows that exogenously added BDNF or NT-4 for $1 \mathrm{~h}$ does not significantly change the size of the evoked EPP. Also, in continuously stimulated neuromuscular preparations at $1 \mathrm{~Hz}$, neither BDNF nor NT-4 was able to modify the EPP amplitude (data not shown). In addition, we investigated a possible short-term effect of exogenously added BDNF on activity-dependent synaptic depression (induced with $40 \mathrm{~Hz}$ trains for $2 \mathrm{~min}$ ) and found any change in the rate of EPP decrement between control and BDNF-treated muscles (control EPP amplitude reduction, $58.34 \pm 33.91 \%$; in BDNF incubated muscles, $57.19 \pm 27.45 \%$; $p<0.05 ; n=7$ single-fiber experiments). However, a $5 \mathrm{~h}$ time-course study (Fig. $2 \mathrm{~B}$ ) showed that both BDNF (10 nM) and NT-4 (2 nM) significantly increased EPP amplitude after $\sim 3 \mathrm{~h}$ of incubation. No effect was found after $3 \mathrm{~h}$ at $1 \mathrm{~nm} \mathrm{BDNF}$, and no additional increase was observed at $50 \mathrm{~nm}$ (data not show). Preincubation $(1 \mathrm{~h}, 5 \mu \mathrm{g} / \mathrm{ml})$ with the fusion protein trkB-IgG to chelate BDNF/NT-4 completely prevents the potentiating effect (at $3 \mathrm{~h}$ ) of exogenous BDNF or NT-4 at the concentrations used (Fig. $2 \mathrm{~B}$ ). Interestingly, NT-3 was unable to change the EPP size at either $1 \mathrm{~h}$ (in the range $10-200 \mathrm{ng} / \mathrm{ml}$ ) or $3 \mathrm{~h}$ ( $200 \mathrm{ng} / \mathrm{ml}$; the maximum change was $21.26 \pm 16.46 \% ; p>0.05 ; n=3$ muscles; minimum 15 fibers per muscle) (Garcia et al., 2010a,b).

We investigated how the $\operatorname{trkB}$ receptor and the unspecific p $75^{\mathrm{NTR}}$ receptor intervene in the effect of exogenous BDNF and NT-4. Both receptors are involved because pharmacologic trk block (K-252a; $200 \mathrm{nM} ; 1 \mathrm{~h})$ or p75 ${ }^{\mathrm{NTR}}$ block (Pep5; $\left.1 \mu \mathrm{M} ; 1 \mathrm{~h}\right)$ fully prevent the effect of neurotrophins at $3 \mathrm{~h}$ (Fig. $3 A$ ). This indicates that exogenous BDNF or NT-4 act through these recep-
A
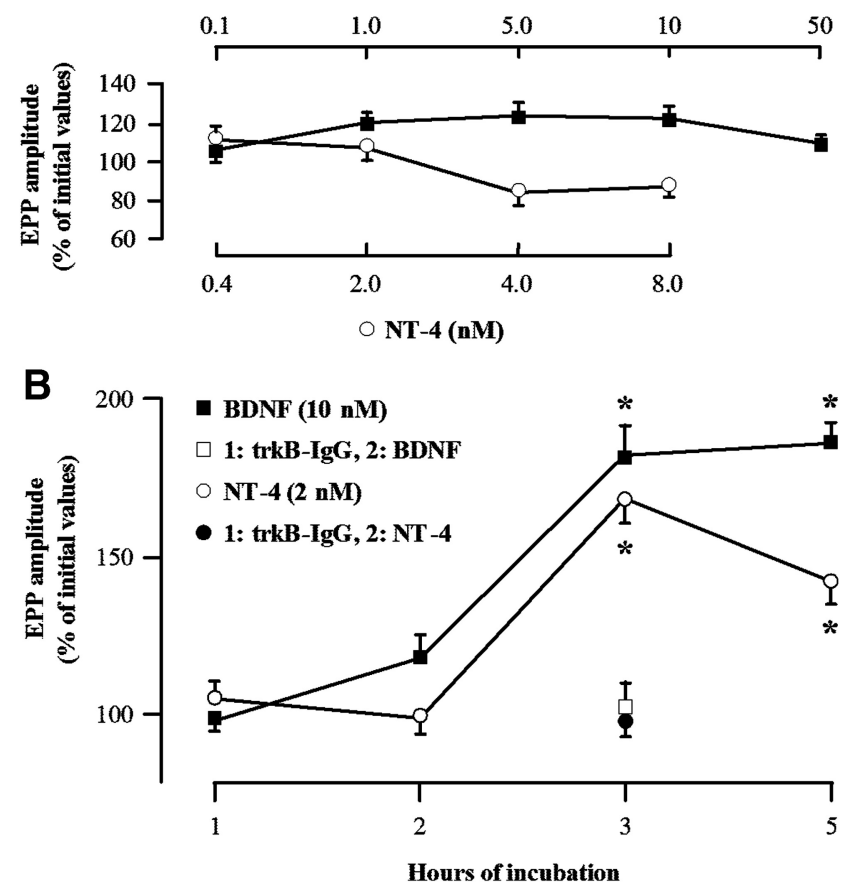

Figure 2. Effect of exogenous BDNF and NT-4 on neuromuscular transmission: dose-response and time course. $A$, Dose-response study showing that incubation with BDNF or NT-4 for $1 \mathrm{~h}$ does not change EPP size. $\boldsymbol{B}$, The time course study showing that after $3 \mathrm{~h}$ of incubation, both BDNF and NT-4 significantly increased EPP amplitude. Preincubation (1 h) with trkB-lgG completely prevents the potentiating effect (at $3 \mathrm{~h}$ ) of the neurotrophins. Five muscles and a minimum of 15 fibers per muscle are included for each point. Values are expressed as mean \pm SEM. ${ }^{*} p<0.05$ with respect to initial values.

tors. Also, for exogenously applied neurotrophins to work, there may need to be a link between the intracellular pathways of both receptors. Figure $3 B$ shows that BDNF and NT-4 do not affect the muscle membrane potential or the size of the spontaneous MEPPs. However, BDNF increases the MEPP frequency at $3 \mathrm{~h}$, whereas NT-4 does not (some representative raw data of the effect of BDNF on MEPP frequency can be seen in Fig. 3C). All of these results suggest that the presynaptic site is the BDNF and NT-4 target that affects neurotransmission.

\section{Endogenous BDNF and NT-4}

We studied how the direct block of the BDNF- and NT-4 receptors trkB and $\mathrm{p} 75^{\mathrm{NTR}}$ affects neurotransmission. The dose-response study (Fig. $4 A$ ) shows that the trk blocker K-252a (200 $\mathrm{nM})$ reduced EPP size $(\sim 50 \%)$ at $1 \mathrm{~h}$ of incubation (Fig. $4 \mathrm{Bii}$, representative raw data). No additional inhibition was observed at high concentrations. This concentration does not change the membrane potential $(99.7 \pm 1.52 \% ; p>0.05)$ or the mean size of the asynchronous unitary quantum events $(102.52 \pm 1.33 \%$; $p>$ $0.05)$, but it does increase their frequency $(174.2 \pm 4.8 \% ; p<$ 0.05) (Fig. $4 B i$, raw MEPP data). However, the $\mathrm{p} 75^{\mathrm{NTR}}$ receptorsignaling inhibitor Pep5 (in the range $50 \mathrm{~nm}$ to $1 \mu \mathrm{M}$ ) does not significantly affect evoked (Fig. $4 A$ ) or spontaneous release parameters $(<10 \%$ variation in MEPP frequency and size; $p>0.05)$ (data not shown). The specificity of the K-252a blocking effect was confirmed by incubating the ex vivo preparation $(1 \mathrm{~h})$ with an anti-trkB antibody (47/trkB) that reduces evoked ACh release as K-252a does (Fig. $4 A$, only one point at $100 \mathrm{~nm}$, Biv, raw data) and also increases MEPP frequency $(206.5 \pm 10 \%$; $p<0.05)$ (Fig. 4 Biii, raw data) with no change in MEPP amplitude or muscle 


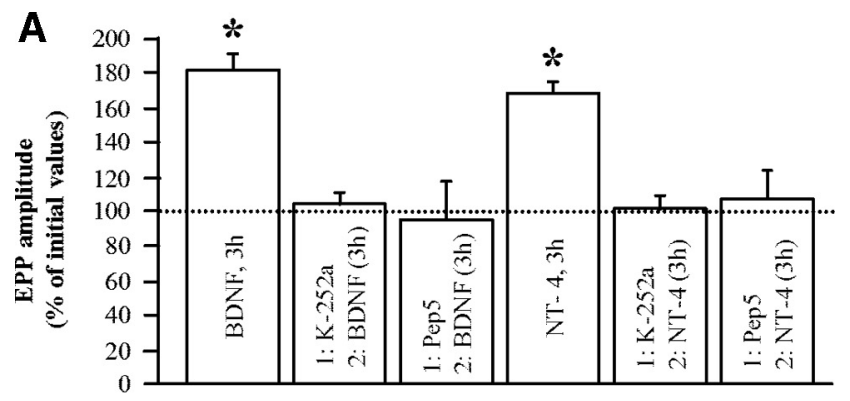

B

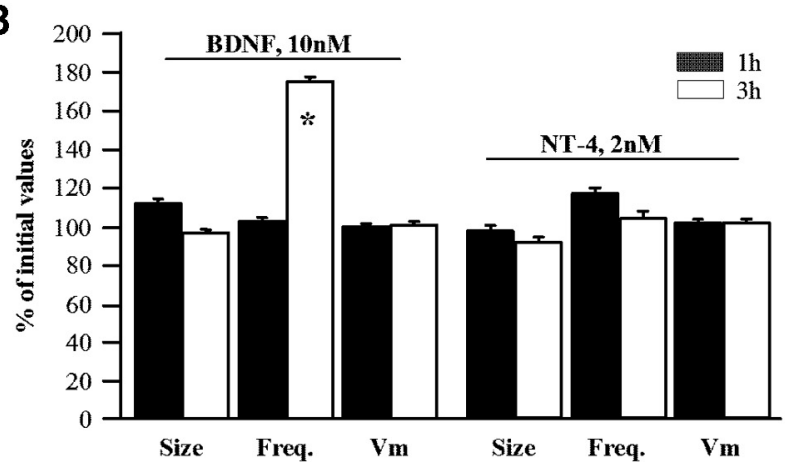

C BDNF, 10nM,1 h

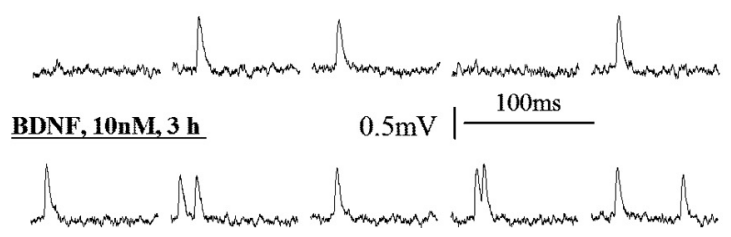

Figure 3. BDNF and NT-4 on neuromuscular transmission. $\boldsymbol{A}$, After trkB block (K-252a) or p75 ${ }^{\text {NTR }}$ block (PEP 5), incubation with 10 nm BDNF or 2 nM NT-4 does not change EPP size after $3 \mathrm{~h} . \boldsymbol{B}$, Spontaneous release (MEPPs) at 1 and $3 \mathrm{~h}$ of incubation. These concentrations of BDNF and NT-4 do not affect the muscle membrane potential or the size of the MEPPs, although the MEPP frequency does increase after $3 \mathrm{~h}$ in the presence of BDNF. $C$, Representative raw data traces show how BDNF affects MEPP frequency (the top and bottom traces were recorded from different fibers). For each column $(\boldsymbol{A}, \boldsymbol{B})$, five muscles and a minimum of 15 fibers per muscle are included. Values are expressed as mean $\pm S E M .{ }^{*} p<0.05$ with respect to initial values.

fiber membrane potential $(<5 \%$; $p>0.05)$ (data not shown). However, the nonpermeant tyrosine kinase blocker K-252b has no effect on transmitter release in our conditions (the maximum change was $11.94 \%$ for $500 \mu \mathrm{M} ; p>0.05 ; n=3$ muscles; minimum 15 fibers per muscle) (Fig. $4 A$ ).

These results may indicate that trkB was continuously coupled to transmitter release and that a physiological amount of endogenous BDNF and/or NT-4 may tonically activate trkB to modulate release, whereas additional, exogenously applied BDNF or NT-4 does not change this normal situation until after $3 \mathrm{~h}$ (see Fig. 2) with the coordinated involvement of $\mathrm{p} 75^{\mathrm{NTR}}$ receptor. To confirm that trkB is continuously activated by endogenous neurotrophins, we treated muscles with the fusion protein trkB-IgG to chelate endogenous BDNF/NT-4. Surprisingly, no changes were observed in ACh release (Fig. 4C) in prolonged incubations ex vivo (3-5 h), nor was ACh release modified after incubation of the neuromuscular preparation with anti-BDNF $(20 \mu \mathrm{g} / \mathrm{ml})$ or anti-NT-4 (10 $\mu \mathrm{g} / \mathrm{ml})$ (Fig. $4 C)$.

Thus, though trkB and $\mathrm{p} 75^{\mathrm{NTR}}$ receptors can be pharmacologically activated by exogenous BDNF or NT-4 to potentiate $\mathrm{ACh}$ release after $3 \mathrm{~h}$, the trkB receptor seems to be normally coupled to ACh release in the absence of a short-term effect of neurotrophins locally at the NMJ.

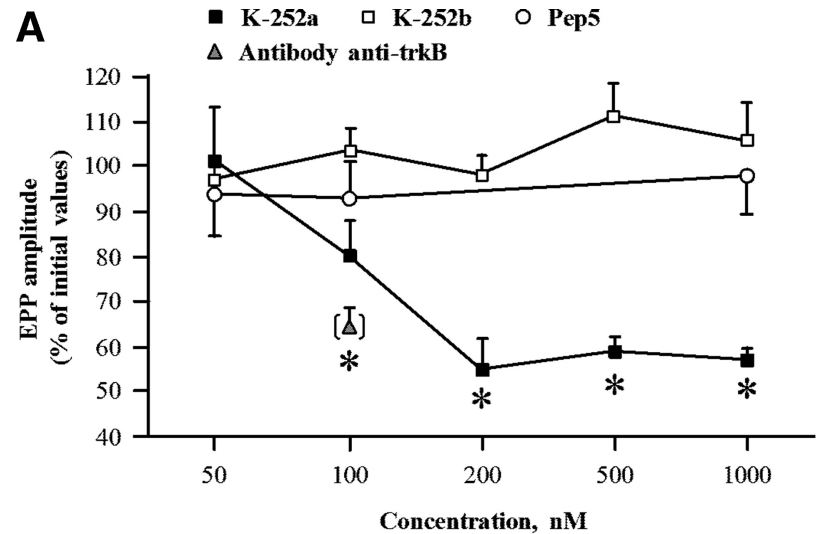

B
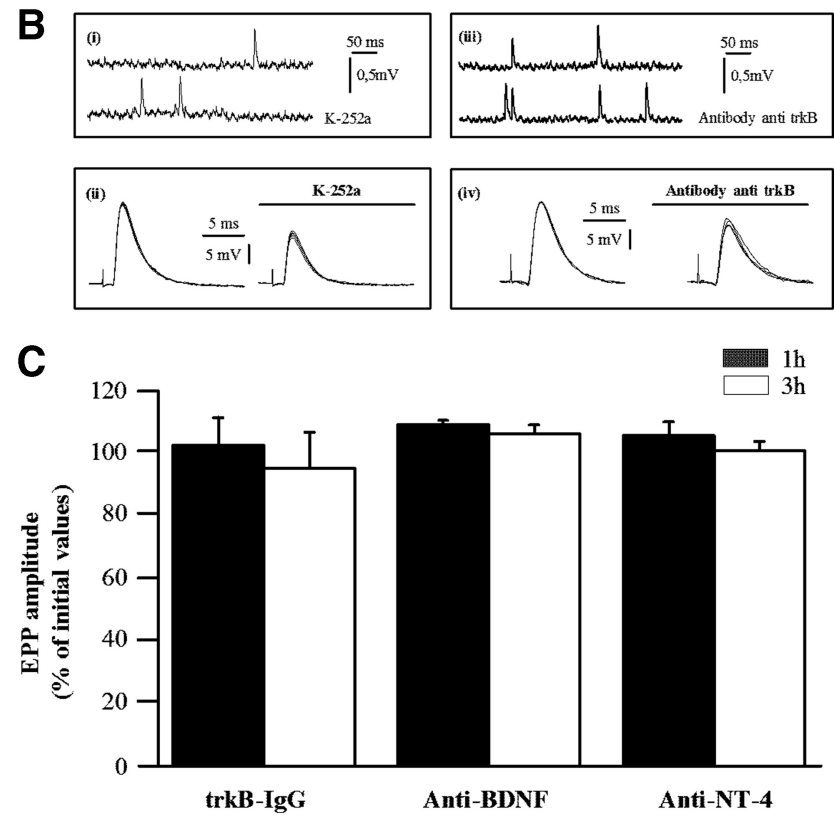

Figure 4. Endogenous BDNF and NT-4. A, B, The dose-response study shows that the trkB blocker K-252a (from $200 \mathrm{~nm}$ ) reduced EPP size at $1 \mathrm{~h}$ of incubation (Bii, raw data; superimposed traces of EPPs) and increased MEPP frequency ( $\boldsymbol{B} \boldsymbol{i}$, representative raw data). However, the p75 ${ }^{\text {NTR }}$ receptor blocker Pep5 (in the range $50 \mathrm{~nm}$ to $1 \mu \mathrm{m}$ ) does not significantly affect evoked (A) and spontaneous release parameters (data not show). The specificity of the K-252a blocking effect was confirmed by the incubation of the ex vivo preparation ( $1 \mathrm{~h}$ ) with an anti-trkB antibody (47/trkB) that reduces evoked ACh release, as K-252a does ( $\boldsymbol{A}$, only one point at $100 \mathrm{~nm}$; Biv, raw data), and similarly increases MEPP frequency (Biii, raw data). The nonpermeant tyrosine kinase blocker $\mathrm{K}-252 \mathrm{~b}(500 \mu \mathrm{M})$ has no effect on transmitter release in our conditions (A). $\boldsymbol{C}$, Incubation with the fusion protein trkB-IgG to chelate endogenous BDNF/NT-4 or with anti-BDNF $(20 \mu \mathrm{g} / \mathrm{ml})$ or anti-NT-4 $(10 \mu \mathrm{g} / \mathrm{ml})$ does not change ACh release. For each point $(\boldsymbol{A})$ and column $(\boldsymbol{C})$, five muscles and a minimum of 15 fibers per muscle are included. Values are expressed as mean \pm SEM. ${ }^{*} p<0.05$ with respect to initial values.

\section{Link between the trkB receptor and the presynaptic} muscarinic receptor pathways

Figure $5 A$ shows that the partial (selective $M_{1}$ receptor block with pirenzepine or $\mathrm{M}_{2}$ block with methoctramine) or total (atropine) block of the mAChR mechanism, the function of which is to modulate ACh release (Slutsky et al., 1999; Minic et al., 2002; Santafé et al., 2003, 2006), prevents exogenous BDNF from carrying out the potentiating action (BDNF produces a change no higher than $\sim 10 \% ; p>0.05)$. These data indicate the importance of the link between the ACh-mAChR pathway and the BDNFtrkB intracellular pathway. Thus, we investigated the hypothesis that the presynaptic muscarinic autoreceptors are involved in trkB coupling to ACh release. We investigated how blocking the trkB 
A

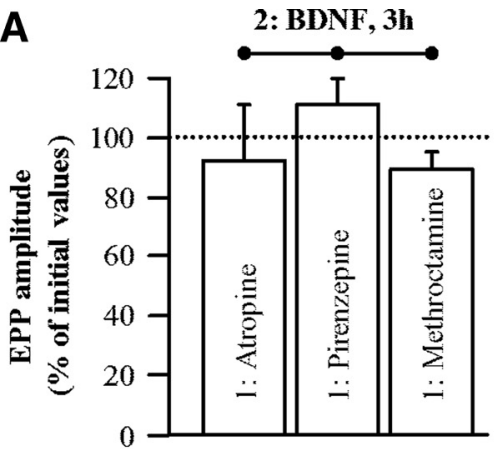

C
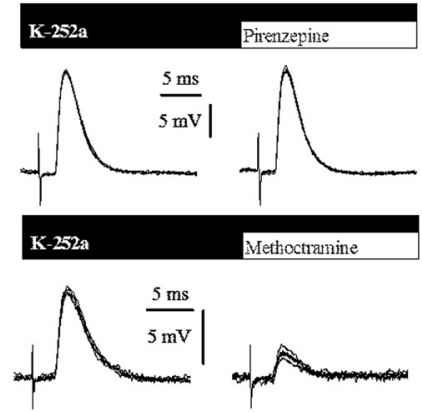

B

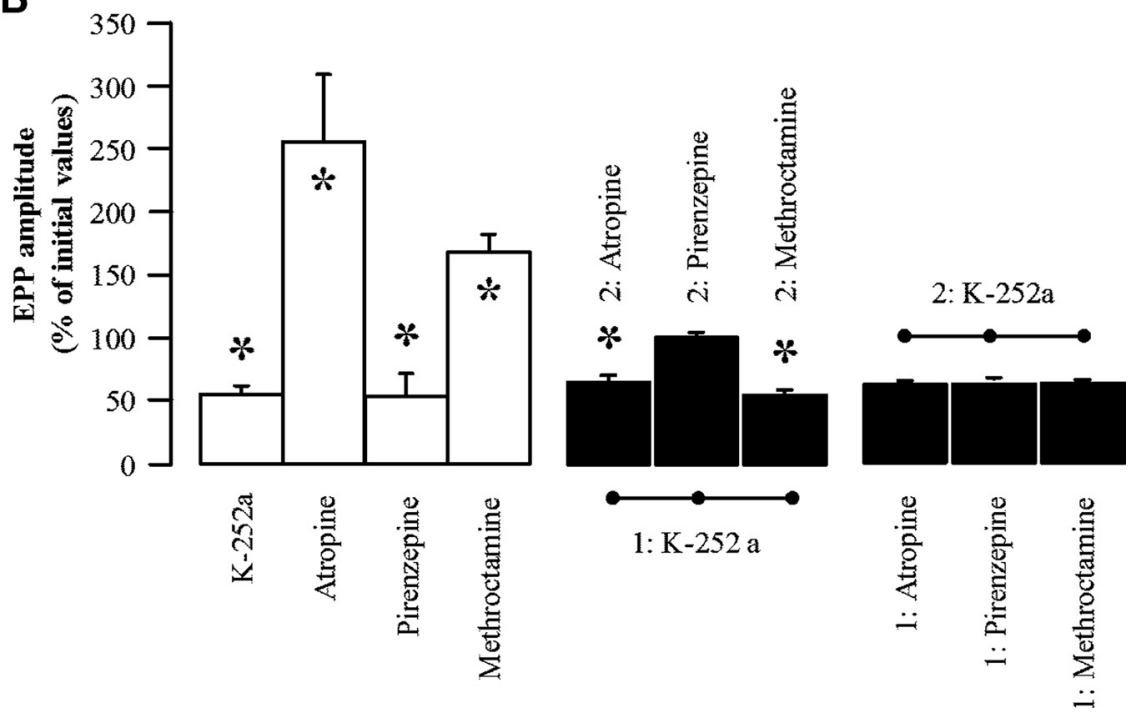

Figure 5. trkB and $m A C h R s$ on $A C h$ release. $A$, In the presence of several blockers of presynaptic $m A C h R$ ( $1 \mathrm{~h}$ of preincubation), BDNF does not have a potentiating action. $B$, Effect (at $1 \mathrm{~h}$ of preincubation) of $\mathrm{K}-252 \mathrm{a}$ and the muscarinic blockers on $\mathrm{ACh}$ release (white columns) in a normal situation. The $M_{1}$ antagonist pirenzepine $(10 \mu \mathrm{M})$ reduced evoked neurotransmission, whereas the $\mathrm{M}_{2}$ antagonist methoctramine $(1 \mu \mathrm{M})$ increased the evoked release. The unselective blockade of both $M_{1}$ and $M_{2}$ with atropine considerably increased release. When $\mathrm{K}$-252a was present, pirenzepine did not affect release, whereas methoctramine and atropine reduced it. The figure also shows the result of the reciprocal experiments (the first $1 \mathrm{~h}$ incubation with an $\mathrm{mAChR}$ blocker followed by a second incubation with K-252a to block trkB). For each column in $\boldsymbol{A}$ and $\boldsymbol{B}$, five muscles and a minimum of 15 fibers per muscle are included. Values are expressed as mean \pm SEM. ${ }^{*} p<0.05$ with respect to initial values. $C$, Raw data for the effect of pirenzepine and methoctramine acting after K-252a preincubation.

signaling cascade affects the functional expression of the presynaptic muscarinic receptor-mediated ACh release-modulatory pathways (Fig. 5B). In normal conditions (normal Ringer's solution), the $\mathrm{M}_{1}$-receptor-selective antagonist pirenzepine $(10 \mu \mathrm{M})$ reduced evoked neurotransmission $(\sim 47 \%)$, whereas the $\mathrm{M}_{2}$ receptor-selective antagonist methoctramine $(1 \mu \mathrm{M})$ increased evoked release $(\sim 67 \%)$. However, the nonselective blockade of both $M_{1}$ and $M_{2}$ with atropine induces a powerful increase in release $(\sim 150 \%)$, suggesting a normal prevalence of the $M_{2}$ pathway, which restricts release (Fig. 5B, white columns). These changes in neurotransmission are presynaptic, and they affect ACh release because the size of the MEPPs was not modified (Santafé et al., 2003). We found that after K-252a preincubation $(1 \mathrm{~h})$, the muscarinic function was fully disturbed. Pirenzepine does not affect release, whereas methoctramine and atropine reduce it. Raw data on the effect of pirenzepine and methoctramine after K-252a preincubation are shown in Figure $5 C$ and indicate that when the trkB receptor is blocked, the $M_{1}$ pathway does not operate, whereas the $\mathrm{M}_{2}$ mechanism reverses their normal coupling to transmitter release. The data also show that, on the

whole, the muscarinic mechanism tonically potentiated release when the trkB pathway had been uncoupled by K-252a.

Figure $5 B$ also shows the result of the same reciprocal experiments (the first $1 \mathrm{~h}$ incubation with an $\mathrm{mAChR}$ blocker followed by a second incubation with K-252a to block trkB, the first substance being present all of the time). The data show that total or partial block of the muscarinic mechanism completely prevents the trkB from coupling to ACh release. This is evidenced by the lack of effect of K-252a after muscarinic block. These experiments suggest that trkB may be tonically coupled to potentiate $\mathrm{ACh}$ release, and this coupling seems not to be mediated by endogenous BDNF/NT-4 but related to the normal operation of mAChRs. Then we used quantitative Western blotting to study the expression and level of the tyrosine phosphorylation of the trkB protein (with antibody anti-phosphorylated tyrosine residues from full-length trkB) (Fig. 6A) when the mAChR mechanism was inhibited. We found that in control resting muscles, trkB is expressed and phosphorylated to some extent (for the quantitation, see Fig. $6 \mathrm{~B}$ ). Preincubation with BDNF (10 nM; $3 \mathrm{~h}$ ) produces a significant though moderate increase in phosphorylation compared with the control (1.4× more). Interestingly, full mAChR block with atropine $(2 \mu \mathrm{M}), \mathrm{M}_{2}$ block with methoctramine $(1 \mu \mathrm{M})$, or $\mathrm{M}_{1}$ block with pirenzepine $(10 \mu \mathrm{M})$ strongly increases the expression and the tyrosine phosphorylation of the trkB protein (1.56-, 1.6-, and 1.78-fold, respectively). The muscarinic mechanism, then, strongly influenced trkB expression and phosphorylation. Figure 6, $C$ and $D$, shows that preincubation with the muscarinic blockers does not change the expression of the BDNF and NT-4 proteins in the muscle.

\section{Discussion}

The expression of neurotrophins and their receptors in muscle and nerve tissues in both development and adulthood has been shown previously (Funakoshi et al., 1993, 1995; Griesbeck et al., 1995; Gonzalez et al., 1999; Ip et al., 2001; Nagano and Suzuki, 2003; Pitts et al., 2006). Here, we show the presence of these molecules in the nerve terminals at adult NMJs (see also Garcia et al., 2010c). In this study, then, we focused on the local effects of the trkB signaling pathway in the NMJ and their relation with the muscarinic pathways in the control of ACh release.

\section{Effect of exogenous BDNF and NT-4 on neuromuscular transmission}

We found a relatively long-term effect of both BDNF and NT-4 on adult neuromuscular transmission: there was a significant increase $(\sim 50 \%)$ in the EPP amplitude at $3 \mathrm{~h}$ of incubation, after which a plateau was reached. Lower doses or shorter times have no effect. This presynaptic effect is specific because it is not pro- 
duced by NT-3 and is prevented by preincubation with the trkB-IgG chimera or by the pharmacologic block of the trkB or p75 ${ }^{\text {NTR }}$ receptors. Also, BDNF moderately increases the level of tyrosine phosphorylation and, therefore, the activation of the trkB receptor. In a previous study, we found that exogenously applied BDNF during development (10 nM for $3 \mathrm{~h}$ ) also increases ACh release from singly and dually innervated synapses at $\mathrm{P} 6-\mathrm{P} 7$ with the involvement of trkB and $\mathrm{p} 75^{\mathrm{NTR}}$ receptors (Garcia et al., 2010b). This effect may be specific to BDNF because NT-4 does not modulate release at P6-P7 (Garcia et al., 2010d). However, it has been reported that low doses of BDNF rapidly induce (within minutes) a trkB-dependent potentiation of both spontaneous and evoked synaptic activity at developing neuromuscular junctions in Xenopus laevis studied in culture (Stoop and Poo, 1996; Boulanger and Poo, 1999; Poo, 2001). In addition to possible species difference, the lack of a short-term effect of neurotrophins on static EPP amplitude in our NMJ model may misrepresent dynamic neuroplasticity effects. However, we investigated a possible short-term effect of exogenously added BDNF on activity-dependent synaptic depression and found any change in the rate of EPP decrement between control and BDNF-treated muscles. Probably, differences in the developmental status and tissue organization of the neuromuscular connections between the Xenopus cultures and the postnatal and adult mammalian LAL muscle should also be considered. The intact tissue organization of the ex vivo LAL muscle may allow continuous local interactions between the presynaptic, postsynaptic, and glial elements. In fact, other authors have found that BDNF by itself has no short-term effect on spontaneous or evoked ACh release in adult mammalian neuromuscular ex vivo preparations (Pousinha et al., 2006; Roux et al., 2006), though other molecular changes have been demonstrated (Mantilla et al., 2004; Roux et al., 2006). The time scale of the neurotrophin action described here is in accordance with other previously published, relatively long-term actions during development. For instance, increasing BDNF levels significantly (by approximately $2 \mathrm{~h}$ ) increased both axon arborization and the number of synapses per axon terminal in developing Xenopus optic axons in vivo (Alsina et al., 2001), and BDNF transiently stabilizes silent synapses in developing mice NMJ (Kwon and Gurney, 1996; Garcia et al., 2010b). However, we do not know if morphologic changes in axonal arborization may occur at this time scale in the adult mammalian NMJs.

We conclude, then, that in the adult mammalian NMJ, exogenously added BDNF or NT-4 produces a trkB and p75 NTR receptor-dependent local modulation of transmitter release on a time scale of several hours. Judging by the blocking experiments presented here, this effect may be (at least for BDNF) dependent on the local mAChR signaling pathways (Fig. $5 A$ ). However, this conclusion should be taken with caution because of the complex interpretation of the pharmacological experiments with muscarinic drugs that are not strictly specific for any receptor subtype.

\section{Endogenous BDNF and NT-4}

Because of the potentiation of ACh release by exogenous BDNF/ NT-4, we investigated the physiological relevance of this pathway. We studied how the direct block of trkB and $\mathrm{p} 75^{\mathrm{NTR}}$ (to

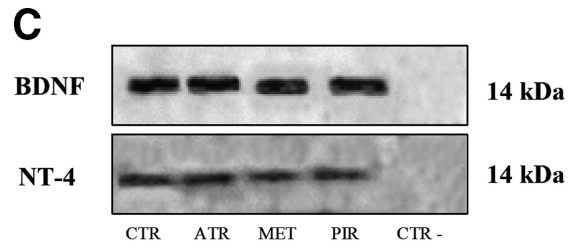

D

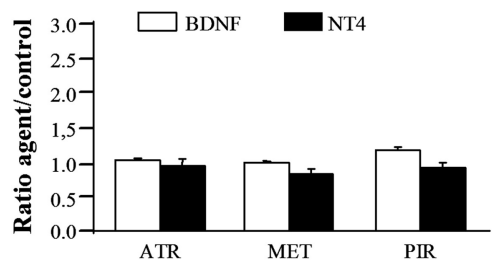

Figure 6. trkB expression and phosphorylation. $A$, Western blotting to see the expression and tyrosine phosphorylation of the 政

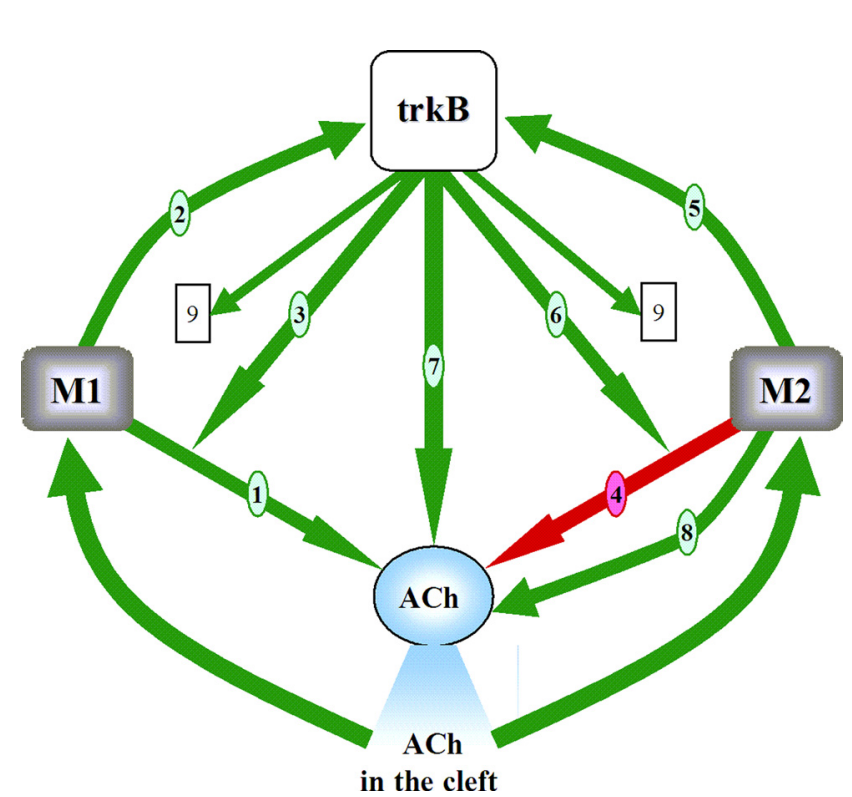

Figure 7. Involvement of $m A C h R s$ and trkB in neurotransmitter release. The diagram shows the main interactions described in this study. The green arrows indicate that the normal coupling of a molecule (trkB, $M_{1}$, or $M_{2}$ ) to ACh release allows normal coupling to the release of the molecule (or the pathway) on the arrowhead. The red arrow indicates inhibitory action. When the trkB receptor is blocked, the $\mathrm{M}_{1}$ release-potentiating pathway (point 1 ) does not operate because it lacks a hypothesized link (point3) that enables the $M_{1}$ mechanism. The $M_{2}$ inhibitory mechanism (point4) reverses its coupling to transmitter release because it lacks a hypothesized link (point 6) that enables this mechanism. In this case, an $\mathrm{M}_{2}$-mediated potentiation (point 8) may be unmasked. A similar reversion in the $\mathrm{M}_{2}$-mediated function occurs in several conditions that share low $\mathrm{ACh}$ release. The low release produced by interference with the trkB receptor (point 7) may be the cause of the functional anomaly in the muscarinic pathway. The reciprocal experiments show that total or partial block of the muscarinic mechanism completely prevents the trkB from coupling to $A C h$ release (points 2 and 5 represent the $m A C h R$ enabling function on the trkB receptor). In the absence of the muscarinic function, the trkB activation may be coupled to mechanisms (point 9) other than immediate transmitter release.

eliminate any effect of endogenous BDNF/NT-4) affects neurotransmission. We used the indolocarbazole K-252a, which has been shown to be a potent, high-affinity though relatively selective inhibitor of trk kinase activity (Tapley et al., 1992). We found 
that a low dose of K-252a reduces ACh release in a short time (1 h), but that the $\mathrm{p} 75^{\mathrm{NTR}}$ receptor blocker Pep5 does not. The specificity of the K-252a blocking effect on trkB was confirmed with the anti-trkB antibody $47 /$ trkB, which reduces evoked ACh release as $\mathrm{K}-252 \mathrm{a}$ does. In addition, the nonpermeant tyrosine kinase blocker K-252b does not change release, and the trkCNT-3 pathway does not seem to be coupled to release in our conditions (Garcia et al., 2010a). These results may indicate that trkB (but not p75 ${ }^{\mathrm{NTR}}$ ) was continuously activated by endogenous BDNF/NT-4 neurotrophins and coupled to transmitter release. However, incubation with the fusion protein trkB-IgG to chelate endogenous BDNF/NT-4 or incubation with anti-BDNF or anti-NT-4 antibodies does not change ACh release. Thus, the trkB receptor seems to be active and coupled to ACh release by a process of transactivation in the absence of a short-term effect of neurotrophins locally at the NMJ (Lee and Chao, 2001). These results do not discount retrograde effects of endogenous BDNF/ $\mathrm{NT}-4$ on a longer time scale in the intact muscle in vivo.

\section{Link between the trkB and muscarinic pathways}

Several developmentally regulated $\mathrm{mAChR}$ subtypes are known to be linked to ACh release at presynaptic sites at the NMJ (Slutsky et al., 1999; Minic et al., 2002; Santafé et al., 2006, 2007). Although the precise cellular localization of the subtypes has not been fully resolved because of the low specificity of the staining antibodies (Pradidarcheep et al., 2008; Wright et al., 2009), pharmacological and electrophysiological experiments show that $M_{1}$ (pirenzepine-sensitive) and $\mathrm{M}_{2}$ (methoctramine-sensitive) subtypes of $\mathrm{mAChR}$ are involved in the enhancement and inhibition of ACh release, respectively, in the adult. Because of the involvement of mAChRs in the effect of exogenous BDNF on ACh release, we investigated how blocking trkB signaling affects the functional expression of $\mathrm{mAChR}$ pathways and vice versa. Figure 7 shows an overall picture, based on the present results, of the relation of the trkB mechanism with mAChRs. We found that blocking the trkB signaling cascade affects the functional expression of the presynaptic $\mathrm{mAChR}$ release-modulatory pathways. The $M_{1}$ release-potentiating pathway (Fig. 7, point 1) (Santafé et al., 2003, 2006) does not operate (it lacks a hypothesized point 3 that enables the $M_{1}$ mechanism), whereas the $M_{2}$ inhibitory mechanism (point 4) (Santafé et al., 2003, 2006) reverses its normal coupling to transmitter release after trkB block, resulting in a clear potentiating effect (point 8). The lack of a hypothesized point 6 that enables the normal $\mathrm{M}_{2}$ inhibitory mechanism may unmask an $\mathrm{M}_{2}$-mediated potentiation. In previous studies, we found similar changes in the $\mathrm{M}_{2}$-mediated $\mathrm{mAChR}$ function (reversion) (Santafé et al., 2006, 2007) in several conditions, all of which have either low ACh release or low ACh in the synaptic cleft: (1) developing synapses in newborn animals, (2) protein kinase A block with $\mathrm{H}-89$, (3) high external magnesium, (4) low external calcium, and (5) increased acetylcholinesterase in the synaptic cleft. Thus, the low release produced by interference with the trkB receptor (point 7) may be the cause of the functional anomaly in the muscarinic pathway. However, in the five situations mentioned above, both $\mathrm{M}_{1}$ and $\mathrm{M}_{2}$ mAChRs stimulate ACh release, whereas $M_{1}$ does not work in the trkB blocked preparation. Interestingly, then, $\mathrm{K}-252 \mathrm{a}$-induced trkB block is the only one of many conditions that inactivates the ACh releaseenhancing $M_{1}$ function. This clearly indicates that the trkB normal function modulates both $\mathrm{M}_{1}$ and $\mathrm{M}_{2}$ muscarinic pathways.

The reciprocal experiments show that total or partial block of the muscarinic mechanism completely prevents the trkB from coupling to ACh release (points 2 and 5 represent the $\mathrm{mAChR}$ enabling function on the trkB receptor). The fact that (1) exogenous BDNF and NT-4 do not have any effect (at $3 \mathrm{~h}$ ) on ACh release when mAChRs are blocked (Fig. 5A), (2) both $\mathrm{M}_{1}$ and $\mathrm{M}_{2}$ muscarinic mechanisms are altered after $\mathrm{K}-252 \mathrm{a}$ incubation, and (3) the short-term $(1 \mathrm{~h})$ trkB-mediated effect on release (shown after K-252a incubation) is eliminated after mAChR inhibition shows the close relation between the two metabotropic receptor pathways ( $\mathrm{mAChR}$ and trkB). This reinforces the suggestion that $\mathrm{mAChRs}$ contribute to the transactivation of the $\operatorname{trkB}$ receptor in normal conditions (Lee and Chao, 2001). The relation between trkB and $\mathrm{mAChRs} \mathrm{seems} \mathrm{more} \mathrm{complex,} \mathrm{however.} \mathrm{The} \mathrm{full} \mathrm{block}$ of the mAChR mechanism with atropine (or the $\mathrm{M}_{1} / \mathrm{M}_{2}$ imbalance with pirenzepine or methoctramine) uncouples trkB from $\mathrm{ACh}$ release, although the expression and phosphorylation of trkB simultaneously increase. We show here that this increase cannot be attributed to an increased production of BDNF or NT-4 induced by the incubation with the muscarinic inhibitors (Fig. 6). This suggests that this trkB activation in the absence or imbalance of the muscarinic function may be related to functions (points 9) other than the immediate transmitter release. In fact, the muscarinic mechanism seems to antagonize trkB expression and phosphorylation and at the same time allow some coupling of the trkB to ACh release.

In summary, we verified the initial hypothesis and found that the normal function of the muscarinic mechanism is a permissive prerequisite for the trkB pathway to couple to ACh release. Reciprocally, the trkB normal function modulates the muscarinic pathways.

\section{References}

Alsina B, Vu T, Cohen-Cory S (2001) Visualizing synapse formation in arborizing optic axons in vivo: dynamics and modulation by BDNF. Nat Neurosci 4:1093-1101.

Barbacid M (1994) The Trk family of neurotrophin receptors. J Neurobiol 25:1386-1403

Barde YA, Edgar D, Thoenen H (1982) Purification of a new neurotrophic factor from mammalian brain. EMBO J 1:549-553.

Bibel M, Barde YA (2000) Neurotrophins: key regulators of cell fate and cell shape in the vertebrate nervous system. Genes Dev 14:2919-2937.

Boulanger LM, Poo MM (1999) Presynaptic depolarization facilitates neurotrophin-induced synaptic potentiation. Nat Neurosci 2:346-351.

Caulfield MP (1993) Muscarinic receptors-characterization, coupling and function. Pharmacol Ther 58:319-379.

Correia-de-Sa P, Sebastiao AM, Ribeiro JA (1991) Inhibitory and excitatory effects of adenosine receptor agonists on evoked transmitter release from phrenic nerve ending of the rat. Br J Pharmacol 103:1614-1620.

Daub H, Weiss FU, Wallasch C, Ullrich A (1996) Role of transactivation of the EGF receptor in signalling by G-protein-coupled receptors. Nature 379:557-560.

Fischer OM, Hart S, Gschwind A, Ullrich A (2003) EGFR signal transactivation in cancer cells. Biochem Soc Trans 31:1203-1208.

Funakoshi H, Frisen J, Barbany G, Timmusk T, Zachrisson O, Verge VM, Persson H (1993) Differential expression of mRNAs for neurotrophins and their receptors after axotomy of the sciatic nerve. J Cell Biol 123:455-465.

Funakoshi H, Belluardo N, Arenas E, Yamamoto Y, Casabona A, Persson H, Ibanez CF (1995) Muscle-derived neurotrophin-4 as an activitydependent trophic signal for adult motor neurons. Science 268: 1495-1499.

Garcia N, Santafé MM, Salon I, Lanuza MA, Tomàs J (2005) Expression of muscarinic acetylcholine receptors (M1-, M2-, M3- and M4-type) in the neuromuscular junction of the newborn and adult rat. Histol Histopathol 20:733-743.

Garcia N, Santafé MM, Tomàs M, Lanuza MA, Besalduch N, Tomàs J (2010a) Involvement of neurotrophin-3 (NT-3) in the functional elimination of synaptic contacts during neuromuscular development. Neurosci Lett 473:141-145.

Garcia N, Santafé MM, Tomàs M, Lanuza A, Besalduch B, Tomàs J (2010b) 
Involvement of brain-derived neurotrophic factor (BDNF) in the functional elimination of synaptic contacts at polyinnervated neuromuscular synapses during development. J Neurosci Res 88:1406-1419.

Garcia N, Tomàs M, Santafé MM, Lanuza MA, Besalduch N, Tomàs J (2010c) Localization of brain-derived neurotrophic factor, neurotrophin-4, tropomyosin-related kinase b receptor, and p75NTR receptor by high-resolution immunohistochemistry on the adult mouse neuromuscular junction. J Peripher Nerv Sys 15:40-49.

Garcia N, Santafé MM, Tomàs $M$, Lanuza MA, Besalduch N, Tomàs J (2010d) Neurotrophin- 4 couples to locally modulated ACh release at the end of neuromuscular synapse maturation. Neurosci Lett 468:72-74.

Gonzalez M, Ruggiero FP, Chang Q, Shi YJ, Rich MM, Kraner S, BaliceGordon RJ (1999) Disruption of Trkb-mediated signaling induces disassembly of postsynaptic receptor clusters at neuromuscular junctions. Neuron 24:567-583.

Griesbeck O, Parsadanian AS, Sendtner M, Thoenen H (1995) Expression of neurotrophins in skeletal muscle: quantitative comparison and significance for motoneuron survival and maintenance of function. J Neurosci Res 42:21-33.

Ip FC, Cheung J, Ip NY (2001) The expression profiles of neurotrophins and their receptors in rat and chicken tissues during development. Neurosci Lett 301:107-110.

Kwon YW, Gurney ME (1996) Brain-derived neurotrophic factor transiently stabilizes silent synapses on developing neuromuscular junctions. J Neurobiol 29:503-516.

Laemmli UK (1970) Cleavage of structural proteins during the assembly of the head of bacteriophage T4. Nature 227:680-685.

Lanuza MA, Besalduch N, Garcia N, Sabate M, Santafé MM, Tomàs J (2007) Plastic-embedded semithin cross-sections as a tool for high-resolution immunofluorescence analysis of the neuromuscular junction molecules: Specific cellular location of protease-activated receptor-1. J Neurosci Res $85: 748-756$.

Lee FS, Chao MV (2001) Activation of Trk neurotrophin receptors in the absence of neurotrophins. Proc Natl Acad Sci U S A 98:3555-3560.

Lewin GR, Barde YA (1996) Physiology of the neurotrophins. Annu Rev Neurosci 19:289-317.

Mantilla CB, Zhan WZ, Sieck GC (2004) Neurotrophins improve neuromuscular transmission in the adult rat diaphragm. Muscle Nerve 29:381-386.

McLachlan EM, Martin AR (1981) Non-linear summation of end-plate potentials in the frog and mouse. J Physiol 311:307-324.

Minic J, Molgo J, Karlsson E, Krejci E (2002) Regulation of acetylcholine release by muscarinic receptors at the mouse neuromuscular junction depends on the activity of acetylcholinesterase. Eur J Neurosci 15:439_ 448.

Nagano M, Suzuki H (2003) Quantitative analyses of expression of GDNF and neurotrophins during postnatal development in rat skeletal muscles. Neurosci Res 45:391-399.

Pitts EV, Potluri S, Hess DM, Balice-Gordon RJ (2006) Neurotrophin and Trk-mediated signaling in the neuromuscular system. Int Anesthesiol Clin 44:21-76.

Poo MM (2001) Neurotrophins as synaptic modulators. Nat Rev Neurosci $2: 24-32$.
Pousinha PA, Diogenes MJ, Ribeiro JA, Sebastiao AM (2006) Triggering of BDNF facilitatory action on neuromuscular transmission by adenosine A2A receptors. Neurosci Lett 404:143-147.

Pradidarcheep W, Labruyere WT, Dabhoiwala NF, Lamers WH (2008) Lack of specificity of commercially available antisera: better specifications needed. J Histochem Cytochem 56:1099-1111.

Roux PP, Barker PA (2002) Neurotrophin signaling through the p75 neurotrophin receptor. Prog Neurobiol 67:203-233.

Roux S, Saint Cloment C, Curie T, Girard E, Mena FJ, Barbier J, Osta R, Molgo J, Brulet P (2006) Brain-derived neurotrophic factor facilitates in vivo internalization of tetanus neurotoxin C-terminal fragment fusion proteins in mature mouse motor nerve terminals. Eur J Neurosci 24:1546-1554.

Santafé MM, Salon I, Garcia N, Lanuza MA, Uchitel OD, Tomàs J (2003) Modulation of ACh release by presynaptic muscarinic autoreceptors in the neuromuscular junction of the newborn and adult rat. Eur J Neurosci 17:119-127.

Santafé MM, Salon I, Garcia N, Lanuza MA, Uchitel OD, Tomàs J (2004) Muscarinic autoreceptors related with calcium channels in the strong and weak inputs at polyinnervated developing rat neuromuscular junctions. Neuroscience 123:61-73.

Santafé MM, Sabate MM, Garcia N, Ortiz N, Lanuza MA, Tomàs J (2005) Changes in the neuromuscular synapse induced by an antibody against gangliosides. Ann Neurol 57:396-407.

Santafé MM, Lanuza MA, Garcia N, Tomàs J (2006) Muscarinic autoreceptors modulate transmitter release through protein kinase $\mathrm{C}$ and protein kinase A in the rat motor nerve terminal. Eur J Neurosci 23:2048-2056.

Santafé MM, Lanuza MA, Garcia N, Tomàs M, Tomàs J (2007) Coupling of presynaptic muscarinic autoreceptors to serine kinases in low and high release conditions on the rat motor nerve terminal. Neuroscience 148: 432-440.

Slutsky I, Parnas H, Parnas I (1999) Presynaptic effects of muscarine on ACh release at the frog neuromuscular junction. J Physiol 514:769-782.

Song WJ, Tkatch T, Surmeier DJ (2000) Adenosine receptor expression and modulation of $\mathrm{Ca}(2+)$ channels in rat striatal cholinergic interneurons. J Neurophysiol 83:322-332.

Stoop R, Poo MM (1996) Synaptic modulation by neurotrophic factors: differential and synergistic effects of brain-derived neurotrophic factor and ciliary neurotrophic factor. J Neurosci 16:3256-3264.

Tapley P, Lamballe F, Barbacid M (1992) K252a is a selective inhibitor of the tyrosine protein kinase activity of the trk family of oncogenes and neurotrophin receptors. Oncogene 7:371-381.

Wang XH, Poo MM (1997) Potentiation of developing synapses by postsynaptic release of neurotrophin-4. Neuron 19:825-835.

Wiese S, Jablonka S, Holtmann B, Orel N, Rajagopal R, Chao MV, Sendtner M (2007) Adenosine receptor A2A-R contributes to motoneuron survival by transactivating the tyrosine kinase receptor TrkB. Proc Natl Acad Sci U S A 104:17210-17215.

Wright MC, Potluri S, Wang X, Dentcheva E, Gautam D, Tessler A, Wess J, Rich MM, Son YJ (2009) Distinct muscarinic acetylcholine receptor subtypes contribute to stability and growth, but not compensatory plasticity, of neuromuscular synapses. J Neurosci 29:14942-14955. 